\title{
The MNC Knowledge Transfer, Subsidiary Absorptive Capacity and HRM
}

Minbaeva, Dana; Pedersen, Torben; Björkman, Ingmar; Fey, Carl; Park, Hyeon Jeong

Document Version

Final published version

Publication date:

2001

License

CC BY-NC-ND

Citation for published version (APA):

Minbaeva, D., Pedersen, T., Björkman, I., Fey, C., \& Park, H. J. (2001). The MNC Knowledge Transfer, Subsidiary Absorptive Capacity and HRM. Department of International Economics and Management, Copenhagen Business School. Working Paper / Department of International Economics and Management, Copenhagen Business School No. 14-2001

Link to publication in CBS Research Portal

\section{General rights}

Copyright and moral rights for the publications made accessible in the public portal are retained by the authors and/or other copyright owners and it is a condition of accessing publications that users recognise and abide by the legal requirements associated with these rights.

\section{Take down policy}

If you believe that this document breaches copyright please contact us (research.lib@cbs.dk) providing details, and we will remove access to the work immediately and investigate your claim. 


\section{Dana Minbaeva \\ Torben Pedersen \\ Ingmar Björkman}

Carl F. Fey

H.J. Park

The MNC Knowledge Transfer, Subsidiary Absorptive Capacity and HRM

WP 14-2001 


\title{
MNC Knowledge Transfer, Subsidiary Absorptive Capacity and HRM
}

\author{
Dana Minbaeva \\ Copenhagen Business School \\ Howitzvej 60, 1 sal \\ DK 2000 Copenhagen \\ Denmark \\ Tel.w. 45-3815-2527 \\ dm.int@cbs.dk \\ Torben Pedersen \\ Copenhagen Business School \\ Ingmar Björkman \\ Swedish School of Economics, Helsinki, Finland \\ and \\ INSEAD
}

Carl F. Fey

Stockholm School of Economics

and

Stockholm School of Economics in Saint Petersburg

\author{
H. J. Park \\ Cornell University
}

December $5^{\text {th }}, 2001$

The authors would like to thank Chris Brewster and participants at the Nordic-IB Workshop for comments on an earlier version of this paper as well as the Swedish Research Council for financial support of this study. 


\begin{abstract}
Based on a sample of 169 subsidiaries of MNCs operating in USA, Russia, and China, this paper investigates the relationship between MNC subsidiary HRM practices, absorptive capacity and knowledge transfer. The paper makes two key contributions. First, the paper examines the relationship between the application of specific HRM practices and the level of the absorptive capacity. Second, the paper suggests that absorptive capacity should be conceptualized as being comprised of two dimensions - ability and motivation. Further, results indicate that the interaction of ability and motivation (absorptive capacity) significantly facilitate transfer of knowledge from other parts of the MNC.
\end{abstract}




\section{INTRODUCTION}

Recent research emphasizes that the ability to create and transfer knowledge internally is one of the main competitive advantages of multinational corporations (MNCs) compared with their domestic counterparts. Indeed, Kogut and Zander (1993) emphasized that the MNCs' ability to transfer knowledge more effectively and efficiently than the market is the primary reason for their existence. The MNC is considered to be a "differentiated network", where knowledge is created in various parts of the MNC and transferred to several interrelated units (Hedlund, 1986; Bartlett and Ghoshal, 1989). The conceptualization of MNCs as differentiated networks has inspired a recent stream of research on the creation, assimilation and diffusion of internal MNC knowledge.

It has been proposed that absorptive capacity,--the "ability to recognize the value of new external information, assimilate it, and apply it to commercial ends" (Cohen and Levinthal, 1990: 128)--of the receiving unit is the most significant determinant of internal knowledge transfer in MNCs (Lane and Lubatkin, 1998; Gupta and Govindarajan, 2000). Subsidiaries differ in their absorptive capacity, and this affects the effectiveness of MNC internal knowledge transfer to subsidiaries. In recent studies absorptive capacity has been treated as a cognitive barrier to knowledge transfer. Motivational factors associated with the parties involved have been viewed as a separate group of factors influencing knowledge transfers (e. g. , Szulanski, 1996; Lane and Lubatkin, 1998; Gupta and Govindarajan, 2000). In this paper we argue that subsidiary absorptive capacity is a function of both competency and motivation. In other words, subsidiary absorptive capacity has to be examined along two dimensions -- ability to recognize the value of new information, assimilate and commercialize it 
and drive to do so. Rather than each of these separately, it is the interactive effect that actually matters for knowledge reception.

Organizations can institute various internal policies, structures and processes to enhance the creation and development of absorptive capacity. It is a commonlyaccepted idea that organizational learning is closely linked with how the organization manages its human resources (e. g. Lado and Wilsson, 1994; Kamoche, 1997). For instance, limited investments in training and development may result in low levels of employee knowledge and skills, thereby inhibiting learning. In their study of relative absorptive capacity and interorganizational learning, Lane and Lubatkin (1998) named both compensation practices and organizational structures as being positively associated with absorptive capacity as well as interorganizational learning. However, our knowledge of how human resource management (HRM) influences absorptive capacity of a subsidiary and knowledge transfer is still very rudimentary. Drawing on research on HRM and organizational performance, we hypothesize that greater use of certain HRM practices will increase the absorptive capacity of the subsidiary, and thus enhance its reception of knowledge from other MNC units.

In sum, our contributions in this paper are, first, to examine how different dimensions of absorptive capacity - employee ability and motivation - together affect the transfer of MNC--knowledge to a particular subsidiary. Second, we also examine the relationship between the application of specific HRM practices and the level of the absorptive capacity in terms of employee ability and motivation. Both contributions are, to our knowledge, novel to the literature. The hypotheses related to how HRM practices and absorptive capacity influence knowledge transfer are tested on a unique data set consisting of 169 MNC subsidiaries located in Finland, Russia and the United States. 


\section{KNOWLEDGE TRANSFER WITHIN MNCS}

There is an increasing interest in investigating knowledge, its sources and transfer in multinational corporations--MNCs (Gupta and Govindarajan, 2000). MNCs are no longer seen as repositories of their national imprint but rather as instruments whereby knowledge is transferred across subsidiaries, thereby contributing to further knowledge development. A common theme in this line of research is that MNCs might develop knowledge in one location and then exploit it in other locations, implying internal transfer of knowledge by MNCs. Thus, the advantage that MNCs enjoy is contingent upon their ability to facilitate and manage inter-subsidiary transfer of knowledge. Hedlund (1986) and Bartlett and Ghoshal (1989), for example, focused on how to organize and structure MNCs in order to facilitate the internal flow and transfer of knowledge in MNCs.

The concept of knowledge transfer itself is rather difficult to capture. In this study the word transfer is used rather than transmission, or translation, to emphasize (following, Szulanski, 1996) that "the movement of knowledge within the organization is a distinct experience, not a gradual process of dissemination, and depends on the characteristics of everyone involved" (p. 28). Transfer of knowledge does not denote a full replication of the knowledge in the receiving unit. Indeed, knowledge is often modified in the receiving unit. The key element in knowledge transfer is not the underlying (original) knowledge, but rather the extent to which the receiving subsidiary receives potentially-useful knowledge and utilizes this knowledge in its own operations.

Prior research on knowledge transfer has attempted to identify factors that inhibit or facilitate knowledge transfer between MNC units. Szulanski (1996) 
explored "internal stickiness" of knowledge, i. e., factors that impede the intra-firm transfer of knowledge. He identified two sets of factors that create internal stickiness of knowledge in firms and impede their internal transfer: motivational factors and knowledge-related factors. The latter stem from the tacit, context-specific and ambiguous kind of knowledge which is difficult to transfer from one location to another, while the former is related to the motivation to apply the necessary time and resources to conduct the transfer. Simonin (1999), in his study of knowledge transfer in strategic alliances, found that knowledge ambiguity plays a critical role as mediator between explanatory variables (e.g., tacitness, prior experience, complexity, cultural distance and organizational distance) and transfer outcomes. These effects were found to be moderated by the learning capacity of the firm. In their study of intrafirm knowledge transfer within MNCs, Gupta and Govindarajan (2000) observe that, the knowledge inflows into a subsidiary are positively associated with the richness of transmission channels, the motivation to acquire knowledge, and the capacity to absorb incoming knowledge.

Two factors of particular importance to determining the transfer outcome stand out in the review of previous studies on knowledge transfer. These are the absorptive capacity of the receiving unit and the motivation to acquire knowledge, where absorptive capacity has been treated mainly as a cognitive barrier distinct from motivational factors (e. g. , Szulanski, 1996; Lane and Lubatkin, 1998; Gupta and Govindarajan, 2000). Motivational factors have most often been considered separately from absorptive capacity--for example, lack of motivation of the source and the recipient of knowledge in Szulanski (1996) and motivational disposition of the source and the target units in Gupta and Govindarajan (2000). Subsidiary motivation to acquire knowledge is important as the new knowledge may disrupt 
current organizational practices and working routines. Knowledge transfer may require substantial investments in time and efforts that may not be viewed as worthwhile to undertake (Szulanski, 1996). The core of Szulanski's argument is based on the assumption of actors who evaluate whether or not it is in their interest to engage in activities as senders and receivers of knowledge. One issue is the question of who will bear the costs of transfer. A second issue is whether knowledge transfer will lead to the sender giving up control over unique knowledge that provides it with strong bargaining power in the MNC.

However, whether subsidiary motivation to transfer and receive knowledge is assumed to be a serious obstacle to knowledge transfer depends on whether one applies a static or dynamic perspective. As pointed out by Foss and Pedersen (2002), in a dynamic setting knowledge exchange among MNC units may catch on so that subsidiaries are motivated to transfer knowledge to each other through the discipline of repeated dealings (Klein and Leffner, 1981). In this setting the parties actively involved in knowledge transfer are likely to gain power and influence within the MNC. Additionally, it has been shown that MNC--internal knowledge transfer tends to be reciprocal, i. e. knowledge is being transferred in both directions (Bresman etal., 1999). In sum, from a dynamic perspective it can be assumed that subsidiaries will be motivated to engage in knowledge transfer.

In this paper we argue that the motivation of the subsidiary employees to contribute to company performance in accordance with the objectives of their organization serves as an important determinant of MNC internal knowledge transfer. Subsidiaries with motivated employees will be more interesting as exchange partners for other MNC units and they will also be better equipped to acquire and use the knowledge that they receive. In the next section we will argue that subsidiary 
absorptive capacity must include both the ability to acquire knowledge and the motivation to do so, since ability without motivation and vice versa are likely to result in poor performance.

Previous studies have paid very little attention to how absorptive capacity is created and developed in the firm. This is more or less taken for granted in the studies. For example, little attention is being paid to which HRM practices and organizational mechanisms may increase absorptive capacity and help diffuse valuable knowledge inside the firm. In the conclusions of the few studies that have included organizational aspects (e. g. Lane and Lubatkin, 1998; Gupta and Govindarajan, 2000) we often find calls for further research on "the learning capacities of organizational units," "organizational mechanisms to facilitate knowledge acquisition," etc. Clearly, in the literature the characteristics of transfer of knowledge have seldom been consistently taken to be endogenous to organizational processes and arrangements (Foss and Pedersen, 2002). In this paper we intend to treat absorptive capacity endogenously by identifying and including the organizational mechanisms (HRM practices) which shape the absorptive capacity of the organization.

\section{ABSORPTIVE CAPACITY}

Since the seminal work of Cohen and Levinthal (1990) the concept of absorptive capacity has been used as a key concept for understanding the conditions for effective learning. Cohen and Levinthal (1990) assumed the existence of a current knowledge base being a necessary, but not sufficient condition for the ability to absorb new knowledge: "absorptive capacity is more likely to be developed and maintained as $a$ byproduct of routine activity when the knowledge domain that the firm wishes to 
exploit is closely related to its current knowledge base" (p. 150). Their followers operationalized absorptive capacity as being connected to the current knowledge base and found absorptive capacity to be positively associated with ratings of the knowledge acquired (Lyles and Salk, 1996; Szulanski, 1996, Mowery, Oxley and Silverman, 1996; Gupta and Govindarajan, 2000; Lane, Salk and Lyles, 2001). However, to achieve a high performance at any level, both the ability and motivation to perform effectively are needed (Baldwin, 1958). The behavioral science literature suggests that both ability and motivation be of importance for individual behavior (Porter and Lawler, 1968). Indeed, few would question the assertion, "if individuals possess the prerequisite ability to learn ... performance will likely be poor if motivation is low or absent" (Baldwin, Magjuka, and Loher, 1991: 52).

There are related debates in the psychology literature between behaviorist and cognitive approaches to learning, distinguishing very clearly between "can do" and "will do" factors (Dunette, 1976). This has been a subject of research and discussion of industrial and educational psychologists for over a half century. The dictionary definition of ability includes certain human attributes, like prior achievement, initial skills, aptitudes, etc. The ability/can do factor usually denotes "a potential for performing some task which may or may not be utilized" (Vroom, 1966:198), while the motivation/will do factor reflects drive.

Beginning with some early human performance models (e.g., Heider, 1958) and continued more recently (e.g., O’Reilly and Chatman, 1994) several authors have suggested an interaction between motivation and ability. Further, Campbell (1976: 64) noted that in industrial and organizational psychology performance is a function of the interaction between ability and motivation. Further, empirical evidence supports rather strongly that there is an interactive, not additive, effect of ability and 
motivation on performance (e. g. French, 1957; Fleishman, 1958; O'Reilly and Chatman, 1994). A frequently appearing expression in industrial and organizational psychology is that "the effects of motivation on performance are dependent on the level of ability of the worker, and the relationship of ability to performance is dependent on the motivation of the worker" (Vroom, 1964: 203).

Applying the concept of the interactive effect of ability and motivation on the issue of knowledge transfer, we expect that a higher rating in knowledge acquired will be achieved, if knowledge receivers have both ability and motivation to absorb new external knowledge. Thus, we propose the following hypothesis:

Hypothesis 1. The interaction between employee abilities and motivation will increase the level of knowledge transfer to the subsidiary

The importance of employing organizational mechanisms for developing the employees' ability and motivation has been recognized for a long time in the HRM literature. In the next section we will discuss the HRM practices that have been identified in the literature as being facilitators of employees' ability and motivation. Our intention is to hypothesize the relationship between the absorptive capacity of units receiving knowledge and the HRM practices that they employ.

\section{HRM PRACTICES}

In his influential study of the impact of "high performance work practices" on organizational turnover, productivity and corporate financial performance, Huselid (1995) factor-analyzed a number of HRM practices and categorized practices into two categories: those mainly influencing employee abilities and those having a greater 
impact on motivation. He found considerable support for the hypothesis that investments in HRM practices are associated with better results--lower employee turnover, greater productivity and improvements in financial performance. Moreover, Huselid (1995) emphasized the interactive effect between HRM practices influencing ability and those influencing motivation, and this was confirmed in statistical tests. Similar results have been obtained by other researchers who have clustered HRM practices in similar 'bundles,' capturing those that influence employees' ability and those that have an impact on employees' motivation (e. g. Arthur, 1994; Ichniowski, Shaw, and Prennushi, 1994; Delaney and Huselid, 1996). However, some studies have identified additional bundles, with a third bundle containing HRM practices employed to structure the work (Delaney and Huselid, 1996) or employee feedback systems (Fey and Bjorkman, 2001). Although the idea of bundles of 'high performance HRM practices' for managing employee ability and motivation has been widely supported, there is little consensus concerning which HRM practices to include in each bundle. Reviews of the literature show that researchers have differed substantially in the HRM practices included in their studies (for a review, see Becker and Gerhart, 1996).

As emphasized by Huselid (1995), HRM practices influence employee skills and competencies through the acquisition and development of a firm's human capital. The competitive advantage of the firm (including foreign subsidiaries) is dependent on the existence of human resources with relevant competence profiles. An analysis of the competencies needed for different positions-together with an analysis of the firm's current pool of employee competencies--helps the organization hire people 
with the desired skills and knowledge. In addition, performance appraisal (or 'performance management') systems help ascertain that employees obtain feedback on their performance and competencies and that measures to enhance their competencies in directions important for the company are being discussed and agreed upon. An integrated part of most performance appraisal systems is also to establish objectives for the employee, thereby establishing targets for the self-development and training for the person. There is also extensive evidence that investments in employee training pay off in terms of enhancing the human capital of the firm and generally a positive relationship has been established between employee training and organizational performance (e. g. , Delaney and Huselid, 1996; Koch and McGrath, 1996).

Thus,

Hypothesis 2. Competence/performance appraisal and training are positively related to subsidiary employee abilities.

"The effectiveness of even highly skilled employees will be limited if they are not motivated to perform" (Huselid, 1995: 637). Recalling the definition of motivation applied earlier, two important issues need to be addressed to facilitate sustainable motivation. First, expectations must exist that specific behaviors will lead to the attainment of certain desired outcomes, incentives and socially-based recognition. Additionally, trust/support that a firm shows towards its employees is likely to be reciprocated by employees engaging actively in behavior that supports the fulfillment of firm objectives.

In this context, several HRM practices may influence individual performance by providing incentives that elicit the appropriate behavior. Such incentive systems may include performance-based compensation that promotes the desired behavior and the 
use of internal promotion systems that focus on employee merit and help employees to overcome invisible barriers to their career growth (Huselid, 1995). Most studies have included performance-based compensation as one of the high performance HRM practices (e. g. , Arthur, 1994; Huselid, 1995; MacDuffie, 1995; Delery and Doty, 1996). Systems that link individual compensation with individual performance, with the group to which s/he belongs or with the whole organization may all contribute to creating additional efforts on the part of the focal employee. While from an expectancy theory point of view it is the existence of a clear linkage between individual effort and reward that matters, from an equity theory (and organizational justice) perspective the main question is whether employees perceive that they receive the rewards that they are entitled to based on their contribution to the organization. Both perspectives would lead us to expect a positive relationship between (well designed) performance-based compensation systems and employee efforts. Promoting employees from within the firm is likely to provide a strong motivation for employees to work hard in order to be promoted (Pfeffer, 1994; Lepak and Snell, 1999). In addition, a philosophy of internal promotion means that a firm has decided to invest in its employees and is thus committed to them. Previous research has shown that employees are more motivated when they know what is going on in the firm. Sharing of information on, for example, strategy and company performance conveys to the employees that they are trusted. Further, it is important that employees know what is going on in a firm so that they can use the knowledge that resides in the firm to its fullest potential (Pfeffer, 1998). As a result, extensive intraorganizational communication is also likely to contribute to employee motivation. Based on the arguments presented above, the following hypothesis is arrived at: 
Hypothesis 3. Performance-based compensation, merit-based promotion and internal communication are positively related to employee motivation.

The conceptual model for empirical testing is presented below.

- INSERT FIGURE 1 HERE -

\section{DATA AND METHOD}

The paper is based on empirical data on foreign-owned subsidiaries located in three countries: Finland, Russia and USA. These countries are different, e.g., in terms of history, culture and management style making it a perfect sample for testing whether the proposed hypotheses on intra-organizational transfer of knowledge cut across the substantial differences in context.

In the USA, lists of subsidiaries of firms from Japan, Germany, Sweden, and Finland which were operating in the USA were obtained from the foreign commercial sections of the respective embassies in the USA. Subsidiaries were randomly selected from the lists and HRM managers or General Managers of the subsidiaries were contacted via phone and asked if they would agree to take part in the study. Those which agreed were faxed or emailed a questionnaire and non-respondents were contacted three times at two-week increments resulting in a $27 \%$ response rate. In Finland, a similar procedure was used and resulted in a 33\% response rate.. In Russia, however, there is little tradition of completing questionnaires and much worry about giving information to unknown people. As a result, based on past experience, interviews were set up with the managers and the questionnaire was completed by the manager during the interview. In a few cases at the manager's request, the questionnaire was left with the manager and collected a few days later. In Russia $28 \%$ of the contacted firms took part in the study. 
The resulting data set consists of 62 subsidiaries operating in Finland, 100 subsidiaries operating in Russia, and 79 subsidiaries operating in USA--giving a total of 241 foreign-owned subsidiaries. However, because of missing values on a number of questions only 169 observations were usable in the subsequent data analysis (Finland 55, Russia 81 and USA 33). No significant difference was found between questionnaires completed by the general manager or the HR manager and thus following Guest (2001) their questionnaires were combined in one data set.

\section{MEASURES}

All data were collected through the questionnaire and the following sections provide the wording used for questionnaire items. All variables were standardized.

Transfer of knowledge. The term of "successful or effective knowledge transfer" was used by Zander (1991) to describe the transfer that results in the receiving unit accumulated or assimilated new knowledge. Following this argumentation, we define the effectiveness of knowledge transfer based on the level of utilization of knowledge that assumes both acquisition and use of new knowledge. Accordingly, in the questionnaire the subsidiaries have been asked to what extent they utilize knowledge from the parent company and from other MNC units (two questions). Respondents have indicated this on a five-point Likert scale, where one indicated no use of MNC knowledge and five indicated substantial use of knowledge from other MNC units. Knowledge transfer is calculated as the average score reported by respondents on the two items (Alpha=0.64).

Employee ability. The construct of employee's ability is capturing the potentials and abilities of the subsidiary employees. This construct was measured by asking respondents to assess the quality of the subsidiary employees relative to the 
employees of the competitors for three items: overall ability, job related skills and educational level. Respondents have indicated this on a seven-point Likert scale going from 1="Far below average" to 7="Far above average" for all three items. In the model used to test our hypotheses we use a composite measure, Employee ability, based on the average across all three items $($ Alpha $=0.77)$.

Employee motivation. The employee motivation construct consists of five items. Two items are measured in a similar way as the above-mentioned construct by asking the respondents to assess the quality of the subsidiary employees relative to the employees of the competitors. This was done for these two items--motivation and work effort--on seven-point Likert-type scales (ranging from 1="far below average" to $7=$ "far above average"). The three other items were measured using a five-point scale (ranging from $1=$ strongly disagree to $5=$ strongly agree) and the respondents were asked to indicate: 1) whether the employees behave in ways that help company performance; 2) whether employees contribute in a positive way to company performance; and 3) whether the subsidiary, compared with the parent company, has a highly motivated group of employees. Employee motivation is a multi-item construct calculated as the average score across these five items $($ Alpha $=0.75)$.

Training. The extent to which the subsidiaries apply the HRM practice of training is measured by two different items. The two items are capturing how many days of formal training managerial and non-managerial employees, respectively, receive annually. Our measure, training, is the average of the individual scores (Alpha $=0$. $83)$.

Competence/performance appraisal. The extent to which competence/performance appraisal is used in the subsidiary is measured by three items. One item measures the proportion of the workforce that regularly receives a formal evaluation of their 
performance (in per cent), one item measures the proportion of jobs where a formal job analysis has been conducted (in per cent), and the third item measures the proportion of new jobs for which a formal analysis of the desired personal skills/competencies/characteristics is carried out prior to making a selection decision (in per cent). Competence/performance appraisal is calculated as the average score reported by respondents across these three items (Alpha $=0.66)$.

Merit-based promotion. The importance put on internal promotion schemes in the subsidiary is measured by three items on five point Likert scales. The first item measures whether qualified employees have the opportunity to be promoted to positions of greater pay and/or responsibility within the subsidiary (1=no opportunities and 5=many opportunities), the second item measures whether the subsidiary places a great deal of importance on merit when making promotion decisions $(1=$ not at all and $5=$ to a large extent $)$, and the third item measures to what extent upper-level vacancies are filled from within $(1=$ not at all and $5=$ to a large extent). Our measure, Merit-based Promotion, is based on the average of these three items (Alpha=0.63).

Performance based compensation. This construct is capturing the extent to which compensation is performance-based in the subsidiary. One item measures the proportion of employees having the opportunity to earn individual, group or company-wide bonuses (per cent), and two items ask the respondents to indicate whether the company uses performance-based compensation $(1=$ not at all and $5=$ to a large extent) and whether the compensation systems are closely connected to the financial results of the subsidiary $(1=$ not at all and $5=$ to a large extent). Taken together these three items make up our index Compensation (Alpha=0. 61 
Internal communication. The extent to which exchange of information is promoted within the organization is measured by three items (all on five-point scales). The three items capture to what extent communication flows well between: 1) employees in different departments, 2) non-managerial employees and managerial employees, and 3) the HR department and the top management team (for all three items $1=$ not at all and $5=$ to a large extent). Internal communication is calculated as the average score reported by respondents across these three items (Alpha $=0.72)$.

Control variables. In the literature of knowledge acquisition, a special focus has been made on studying exogenous variables for knowledge transfer in MNCs. Most of those are interdependent, and some of them are derivatives or combinative results of others. All our hypotheses were tested after controlling for country of origin, subsidiary age, subsidiary size and nature of the industry.

Subsidiary age. The older subsidiary the higher its level of autonomy tends to be. Empirical findings (e. g. , Foss and Pedersen, 2002) indicate that a higher level of innovation in subsidiaries is associated with high autonomy, and since more innovative subsidiaries might be less dependent on knowledge transferred from other MNC units, subsidiary age might be negatively related to the level of knowledge transfer. On the other hand, more innovative subsidiaries may also be more interesting as knowledge exchange partners for other MNC units who therefore are particularly committed to transferring knowledge to the focal subsidiary. Hence, the relationship between subsidiary age and knowledge transfer might also be positive. Subsidiary age is measured as the number of years the subsidiary has operated in the particular country.

Subsidiary size. Arguing along the same line as above, larger subsidiaries may acquire less knowledge from other MNC units than smaller subsidiaries simply 
because they are able to generate more knowledge themselves. Therefore, we expect the relationship between subsidiary age and level of knowledge transfer possibly to be negative. Conversely, again based on the argumentation above, we might find a position relationship between subsidiary size and the utilization of knowledge from other units. The subsidiary size is measured as the logarithm of the total number of employees in the subsidiary.

Subsidiary function. Focusing on subsidiaries, a main distinction can be made between production-oriented and sales/service-oriented subsidiaries, where we expect production-oriented subsidiaries to have more knowledge transfer, because these subsidiaries conduct more knowledge-intensive activities and also because they are likely to be involved in a wider variety of functional activities. The variable is measured as the share of the subsidiaries business that comprises of manufacturing activities.

Host country. Since we expect that differences in local environments -- economic, political, technological and socio-cultural - may affect the process of knowledge transfer, we have included two country dummies for Russia ( $1=$ for Russian subsidiaries, otherwise $=0)$ and Finland $(1=$ for Finnish subsidiaries and otherwise $=0)$. US subsidiaries are then used as the base case with which the two others are compared.

Expatriates. The use of expatriates as a vehicle for knowledge transfer from other MNC units to the focal subsidiary has been extensively discussed in the literature (Downes and Thomas, 2000; Bonache and Brewster, 2001). The higher number of expatriates in a subsidiary, the more knowledge may be transferred via these individuals to the unit. We assume that rather than the absolute number of expatriates, it is their relative share of the total number of subsidiary employees that 
may significantly contribute to the knowledge transfer. Therefore, we controlled for the relative number (in percent) of expatriates in the subsidiary.

\section{RESULTS}

The three hypotheses may be summarized in three basic equations as follows.

1. Employee ability $=$ Competence/Performance appraisal + Training + Error

2. Employee motivation $=$ Merit-based Promotion + Performance-based compensation + Internal Communication + Error

3. Transfer of knowledge $=$ Employee ability + Employee motivation + Employee ability*Employee motivation + Controls + Error

Hypothesis 1 is reflected in model 3, while hypothesis 2 is expressed in model 1, and, finally, hypothesis 3 is expressed in model 2. However, since the above models represent decisions that are interdependent (they should be considered jointly), the use of single equation models may yield biased results and obscure interesting theoretical possibilities. Since the above models are interdependent, then it is possible that the joint optimization of all involved decisions may lead to suboptimization of one or more individual decisions. Statistically the interdependence might be reflected in that error terms of the three models are correlated. Hence the correct model to estimate these decisions is a simultaneous equation model as three-stage least square, that circumvents the problem of interdependence by using instrument variables (often the exogenous variables) to obtain predicted values of the endogenous variables (in our case, knowledge transfer, employee's ability, and employee's motivation).

We have applied the three-stage least square regression techniques (3SLS) with instrument variables to test all three hypotheses simultaneously. All the exogenous 
variables (competence/performance appraisal, training, merit-based promotion, performance-based compensation, internal communication, country dummies, subsidiary age, subsidiary size, and subsidiary function) are used as instrument variables in the estimation of the model. Since the scales of the variables varied considerably, all variables have been standardized (mean=0 and standard deviation=1).

\section{INSERT TABLE 1 HERE}

The correlation coefficients on each of the independent variables are shown in Table 1. There is a relatively high correlation coefficient between the dummy for Russia and the dummy for Finland (0.67), which is as expected given the way the variables were constructed. However, none of the other correlation coefficients reach the usual threshold for detecting multicollinearity problems (i. e. $r>0$. 5), which suggest absence of collinearity in the data set.

The result of the total model is reported in Table 2. Numbers in parentheses represent standard errors.

\section{INSERT TABLE 2 HERE}

Overall, the system of the three equations (models) works well with a system weighted R-square of $0.32^{1}$. This indicates that almost one third of the observed variation in the extent of knowledge transfer is explained by the variables in the model. We turn now to the tests of our explanatory hypotheses.

\footnotetext{
${ }^{1}$ This $\mathrm{R}^{2}$ statistics have been corrected for the fact that the regression sum of squares and the error sum of squares do not sum to the total corrected sum of squares in instruments variables methods (as 3SLS) where first-stage predicted values are substituted for endogenous regressors. Therefore, the overall $\mathrm{R}^{2}$ value might be larger than the $\mathrm{R}^{2}$-values for each of the equations (as in this case). The system weighted $\mathrm{R}^{2}$-value is the best measure of the overall goodness of fit of the model including all three equations.
} 
Hypothesis 2 posited a relationship between the HRM practices of competence/performance appraisal and training and the subsidiary employees' ability. This hypothesis, where the results of the test are shown in column 1 in Table 2, is largely supported. The HRM practices of training have a significantly positive relationship with the employee's ability (significant at 5 per cent level). The effect of performance appraisal on employees' ability is also significantly positive, although only at the 10 per cent level. This indicates that investments in HRM practices (e.g., training) that directly aim at developing and upgrading the skills of the workforce have a somewhat stronger effect on employees' ability than the more indirect (longterm) practices of competence and performance appraisal. Since the variables have been standardized, the two parameters on 0.16 and 0.11 , respectively, also indicate a substantial difference in the effects of these two variables on employee ability.

In the same vein, Hypothesis 3 was concerned with the relationship between the HRM practices of merit-based promotion, performance-based compensation, and internal communication and employee motivation. The results of the test are shown in column 2 in Table 2. Two variables turned out to be significant which lends some support to the hypothesis. The two variables-performance-based compensation and internal communication — are highly significant (at 1 per cent level) with the expected positive sign indicating that they are strong determinants of employees' motivation. Promotion is also positively related with employee motivation, but the relationship does not reach the 10 per cent significance level. An improvement in employee motivation appears, therefore, to be more associated with the use of performancebased compensation and promotion of information sharing within the organization than with merit-based promotions. 
Hypothesis 1 was concerned with the two dimensions of absorptive capacity in the subsidiary, ability and motivation, and more specifically their interaction effect as a facilitator of knowledge transfer in MNCs. The column 3 in Table 2 gives strong support for hypothesis 1. While the main effects of both employee ability and employee motivation are positive but insignificant, the interaction effect between these two variables is highly significant. This indicates that neither employee ability nor motivation in themselves facilitates the knowledge transfer. In order to facilitate the knowledge transfer both dimensions of absorptive capacity--the ability and the motivation of the employees --are needed.

Finally, the only control variable that turned out to be significant was the country dummy for Russia. The significance of the dummy for Russia and insignificance of the Finnish dummy indicate that Russian subsidiaries are receiving more knowledge from other MNC units than the US and Finnish subsidiaries, which makes sense given the attempts for Russian subsidiaries to catch up with the rest of their MNCs.

\section{CONCLUDING COMMENTS}

In this paper, we have addressed the relationship between MNC subsidiary HRM practices, absorptive capacity and knowledge transfer. We found overall support for the argument that the absorptive capacity of the subsidiary facilitates transfer of knowledge from other parts of the MNC. The larger the absorptive capacity, the more effective the transfer of knowledge. Moreover, we find support that both dimensions of or absorptive capacity (ability and motivation) need to be present in order to optimally facilitate knowledge transfer. While much prior research on absorptive capacity has tended to only focus on the ability dimension of absorptive 
capacity, our results indicate that ability is a necessary but not sufficient condition. Ability needs to be combined with employee motivation in order to affect the reception of knowledge from other parts of the MNC.

There exists a large and growing body of research on the relationship between HRM and organizational performance (for reviews, see Becker and Gerhart, 1996; Guest, 1997; Becker and Huselid, 1998). In line with our results, previous research has often bundled different HRM practices into two main categories: those determining employee ability and those determining employee motivation. However, we diverge from previous work on human resource management and firm performance by combining work on HRM and firm performance with research on knowledge transfer within the MNC. The results of the present study indicate not only that extensive use of different HRM practices have positive impacts on the 'HR outcomes' (Guest, 1997) employee ability and motivation. Our research also indicates that investments in employee ability and motivation together have contributed to MNC knowledge transfer to subsidiaries located in Russia, Finland and the United States.

Like all research, the present study has limitations. Similar to many previous studies in this field, most data on HRM practices were collected through perceptual scales. It would also be useful in future studies to collect data on knowledge transfer from other respondents to minimize the risk of common method bias. The validity of the data on employee motivation and ability was also limited by the use of only one respondent per subsidiary. It could also be argued that investments in HRM might have a lagged effect on employee competencies and motivation, and therefore also on knowledge transfer. Finally, other factors potentially influencing knowledge transfer could be controlled for, such as characteristics of the relationship between the parties 
involved, sender characteristics, and characteristics of the knowledge transferred. While this study makes important contributions to our understanding of the relationship between HRM, employee ability and motivation, and knowledge transfer in the MNC, this study is clearly only a first step and additional research is needed on this issue. 


\section{REFERENCES}

Arthur, J. 1994. Effects of Human Resource Systems on Manufacturing Performance and Turnover. Academy of Management Journal 37: 670-687.

Baldwin, A. 1958. The Role of an "Ability” Construct in a Theory of Behaviour. In McClelland, D. Baldwin, A, Bronfenbrenner, U., Strodtbeck, F. Talent and Society. Van Nostrand, Princeton.

Baldwin, T., Magjuka, R., Loher,B. 1991. The Perils of Participation: effects of choice of training on trainee motivation and learning. Personnel Psychology 44: 51-65

Barlett, C., Ghoshal, S. 1989. Managing Across Borders. Boston: Harvard Business School Press.

Becker, B., Gerhart, B. 1996. The impact of human resource management on organizational performance: Progress and prospects. Academy of Management Journal 39: 779-801.

Becker, B. , Huselid, M. A. 1998. High performance work systems and firm performance: A synthesis of research and managerial implications. Research in Personnel and Human Resource Management 16: 53-101.

Bresman, H. , Birkinshaw. J., Nobel, R. 1999. Knowledge Transfer in International Acquisitions. Journal of International Business Studies 30: 439-462.

Cohen, W. , Levinthal, D. 1990. Absorptive Capacity: a new perspective on learning and innovation. Administrative Science Quarterly 35:128-152

Delaney, J., Huselid, M. 1996. The Impact of Human Resource Management Practices on Perceptions of Organizational Performance. Academy of Management Journal 39: 949-969 
Delery, J. E., Doty, H. 1996. Models of theorizing in strategic human resource management: Tests of universalistic, contingency, and configurational performance predictions. Academy of Management Journal 39: 802-835.

Downes, M., Thomas, A. S. 2000. Knowledge Transfer Through Expatriation: The U-curve Approach to Overseas Staffing. Journal of Management Issues 12: 131-149.

Dunette, M. 1976. Handbook of Industrial and Organizational Psychology. Chicago: Rand McNally College Publishing Company

Fey, C. \& Bjorkman, I. 2001: The Effect of Human Resource Management Practices on MNC Subsidiary Performance in Russia. Journal of International Business Studies 32: 59-75.

Fleishman, E. 1958. A Relationship between Incentive Motivation and Ability Level in Psychomotor performance. Journal of Experiential Pscyhology 56: 78-81

Foss, N. \& Pedersen, T. 2001. Building a MNC Knowledge Structure: the roles of knowledge sources, complementarities, and organizational context. Paper presented at the LINK annual conference.

Foss, N., Pedersen, T. 2002. Transferring Knowledge in MNCs: The Roles of Sources of Subsidiary Knowledge and Organizational Context. Journal of International Management. Forthcoming.

French, E. 1957. Effects of Interaction of Achievement, Motivation, and Intelligence on Problem Solving Success. American Psychologist 12: 399-400

Guest, D. 1997. Human Resource Management and Performance: a review and research agenda. The International Journal of Human Resource Management 8: 263-276

Guest, D. 2001. Human Resource Management: When Research Confronts Theory. The International Journal of Human Resource Management 12: 1092-1106.

Gupta, A., Govindarajan, V. 1994. Organizing for Knowledge Flows within MNCs. International Business Review 3: 443-457

Gupta, A. , Govindarajan, V. 2000. Knowledge Flows within MNCs. Strategic Management Journal, 21: 473-496 
Hedlund, G. 1986. The Hypermodern MNC - A Heterarchy? Human Resource Management, Spring, 251: $9-35$

Huselid, M. 1995. The Impact of Human Resource Management Practices on Turnover, Productivity, and Corporate Financial Performance. Academy of Management Journal 38: 635-672

Ichniowski, C. Shaw, K. , Prennushi, G. 1997. The Effects of Human Resource Management Practices on Productivity: a study of steel finishing lines. The American Economic Review 87: 291-313

Kamoche, K. 1997. Knowledge Creation and Learning in International HRM. The International Journal of Human Resource Management 8: 213-225

Klein, B. , Lefler, K. 1981. The role of market forces in assuring contractual performance. Journal of Political Economy 89: 615-641.

Koch, Marianne J. , McGrath, R. G. 1996. Improving labor productivity: Human resource management policies do matter. Strategic Management Journal 17: 335-354.

Kogut, B. , Zander, U. 1993. Knowledge of the Firm and the Evolutionary Theory of the Multinational Corporation. Journal of International Business Studies 24: 625-645

Lado, A. and Wilson, M. 1994. "Human Resource Systems and Sustained Competitive Advantage: a competency-based perspective”. Academy of Management Review 19: 699-727

Lane, P. , Lubatkin, M. 1998. Relative Absorptive Capacity and Interorganizational Learning. Strategic Management Journal 19: 461-477

Lane, P., Salk, J. E., Lyles, M. 2001. Absorptive capacity, learning and performance in international joint ventures. Strategic Management Journal 2212: 1139-1161.

Lepak, D. P. \& Snell. S. A. 1999. The human resource architecture: Towards a theory of human captial allocation and development. Academy of Management Review 24: 31-48.

Lyles, M., Salk, J. 1996. Knowledge Acquisition from Foreign Parents in International Joint Ventures: an empirical examination in the Hungarian context. Journal of International Business Studies, 27: 877903 
MacDuffie, J. P. 1995. Human Resource Bundles and Manufacturing Performance: Flexible production systems in the world auto industry. Industrial Relations \& Labor Review 48: 197-221.

Mowery, D., Oxley, J., Silverman, B. 1996. Strategic Alliances and Interfirm Knowledge Transfer. Strategic Management Journal, Winter Special Issue 17: 77-91

Pfeffer, J. 1994. Competitive advantage through people: Unleashing the power of the work force. Boston: Harvard Business Press.

Pfeffer, J. 1998. The human equation: Building profits by putting people first. Boston: Harvard Business Press.

Simonin, B. 1999 Transfer of Marketing Know-How in International Strategic Alliances: an empirical investigation of the role and antecedents of knowledge ambiguity. Journal of International Business Studies 30, 3: 463-490

Szulanski, G. 1996. Exploring Internal Stickiness: impediments to the transfer of best practice within the firm. Strategic Management Journal, Vol. 17, Winter Special Issue: 27-43

Vroom, V. 1964. Work and Motivation. New York, London and Sydney: John Wiley and Sons, Inc.

Zander, U. 1991. Exploiting a Technological Edge: voluntary and involuntary dissemination of technology. Institute of International Business, Stockholm 
New Refs

Campbell, John P. 1976. Motivation in Industrial and Organizational Psychology. In Marvin D. Dunnette (ed.) Handbook of Indusrial and Organizational Psychology: 63-130. Chicago: Rand McNally.

Heider, Fritz. 1958. The Psychology of Interpersonal Relations. New York: Wiley.

O'Reilly, Charles A. \& Jennifer A. Chatman. 1994. Working Smarter and Harder: A Longitudinal Study of Managerial Success, Administrative Science Quarterly, 39: 603-627.

Bonache, J., Brewster, C. 2001. Knowledge Transfer and the Management of Expatriation.

Thunderbird International Business Review 43(1): 145-168 
Table 1. Correlation matrices including all independent variables (all have mean $=0$ and standard deviation $=1$ )

\begin{tabular}{|c|c|c|c|c|c|c|c|c|c|c|}
\hline & 1 & 2 & 3 & 4 & 5 & 6 & 7 & 8 & 9 & 10 \\
\hline 1) Training & 1.00 & & & & & & & & & \\
\hline $\begin{array}{l}\text { 2) Competence/ } \\
\text { performance appraisal }\end{array}$ & $0.27^{* * *}$ & 1.00 & & & & & & & & \\
\hline 3) Merit-based promotion & $0.17^{* *}$ & 0.09 & 1.00 & & & & & & & \\
\hline $\begin{array}{l}\text { 4) Performance based } \\
\text { compensation }\end{array}$ & $0.25^{* * *}$ & $0.32 * * *$ & $0.34 * * *$ & 1.00 & & & & & & \\
\hline 5) Internal communication & $0.29 * * *$ & $0.27 * * *$ & $0.41 * * *$ & $0.27 * * *$ & 1.00 & & & & & \\
\hline 6) Subsidiary age & $-023^{* * *}$ & -0.07 & 0.01 & 0.04 & $-0.16^{* *}$ & 1.00 & & & & \\
\hline 7) Subsidiary size & $-0.20 * * *$ & -0.06 & 0.09 & 0.06 & $-0.13^{*}$ & $0.41 * * *$ & 1.00 & & & \\
\hline 8) Subsidiary function & 0.02 & 0.01 & -0.04 & -0.03 & 0.05 & -0.07 & $0.15^{* *}$ & 1.00 & & \\
\hline 9) Russia (dummy) & $0.48^{* * *}$ & $0.24 * * *$ & 0.08 & $0.25^{* * *}$ & $0.23 * * *$ & $-0.39 * * *$ & $-0.37 * * *$ & -0.02 & 1.00 & \\
\hline 10) Finland (dummy) & $-0.36 * * *$ & $-0.31 * * *$ & 0.03 & -0.09 & -0.06 & $0.22 * * *$ & $0.23^{* * *}$ & 0.05 & $-0.67 * * *$ & 1.00 \\
\hline 11) Expatriates & 0.07 & 0.05 & $-0.13 *$ & -0.09 & -0.07 & -0.01 & $-0.35 * * *$ & $-0.13^{*}$ & 0.06 & $-0.27 * * *$ \\
\hline
\end{tabular}


Table 2. The three-stage least squares estimation of a simultaneous equation model

\begin{tabular}{|c|c|c|c|}
\hline & $\begin{array}{l}\text { EMPLOYEE } \\
\text { ABILITY }\end{array}$ & $\begin{array}{l}\text { EMPLOYEE } \\
\text { MOTIVATION }\end{array}$ & $\begin{array}{l}\text { TRANSFER OF } \\
\text { KNOWLEDGE }\end{array}$ \\
\hline Intercept & $\begin{array}{l}0.01 \\
(0.07)\end{array}$ & $\begin{array}{l}0.01 \\
(0.07)\end{array}$ & $\begin{array}{c}0.01 \\
(0.08)\end{array}$ \\
\hline Training & $\begin{array}{l}0.16 \\
(0.07)^{* *}\end{array}$ & & \\
\hline $\begin{array}{l}\text { Competence/performance } \\
\text { appraisal }\end{array}$ & $\begin{array}{l}0.11 \\
(0.07)^{*}\end{array}$ & & \\
\hline Merit-based Promotion & & $\begin{array}{l}0.07 \\
(0.07)\end{array}$ & \\
\hline $\begin{array}{l}\text { Performance-based } \\
\text { compensation }\end{array}$ & & $\begin{array}{l}0.20 \\
(0.07)^{* * *}\end{array}$ & \\
\hline Internal Communication & & $\begin{array}{l}0.29 \\
(0.07)^{* * *}\end{array}$ & \\
\hline Employee Ability & & & $\begin{array}{l}0.61 \\
(0.47) \\
\end{array}$ \\
\hline Employee Motivation & & & $\begin{array}{l}0.04 \\
(0.31)\end{array}$ \\
\hline Ability*motivation & & & $\begin{array}{l}0.99 \\
(0.13)^{* * *}\end{array}$ \\
\hline $\begin{array}{l}\text { Controls: } \\
\text { - Subsidiary age } \\
\text { - Subsidiary size } \\
\text { - Subsidiary function } \\
\text { - Russia (dummy) } \\
\text { - Finland (dummy) } \\
\text { - Share of expatriates }\end{array}$ & & & $\begin{aligned} & 0.04(0.08) \\
&-0.01(0.08) \\
&-0.05(0.07) \\
& 0.20(0.12)^{*} \\
& 0.05(0.12) \\
& 0.17(0.11) \\
&\end{aligned}$ \\
\hline $\begin{array}{l}\text { F-value } \\
\text { R-square } \\
\mathrm{N}\end{array}$ & $\begin{array}{l}5.39 * * * \\
0.06 \\
169\end{array}$ & $\begin{array}{l}18.08 * * * \\
0.25 \\
169\end{array}$ & $\begin{array}{l}4.51^{* * *} \\
0.20 \\
169\end{array}$ \\
\hline
\end{tabular}

$* * *, * *$ and $*=$ significant at 1,5 and 10 per cent, respectively 
Figure 1. Conceptual model.

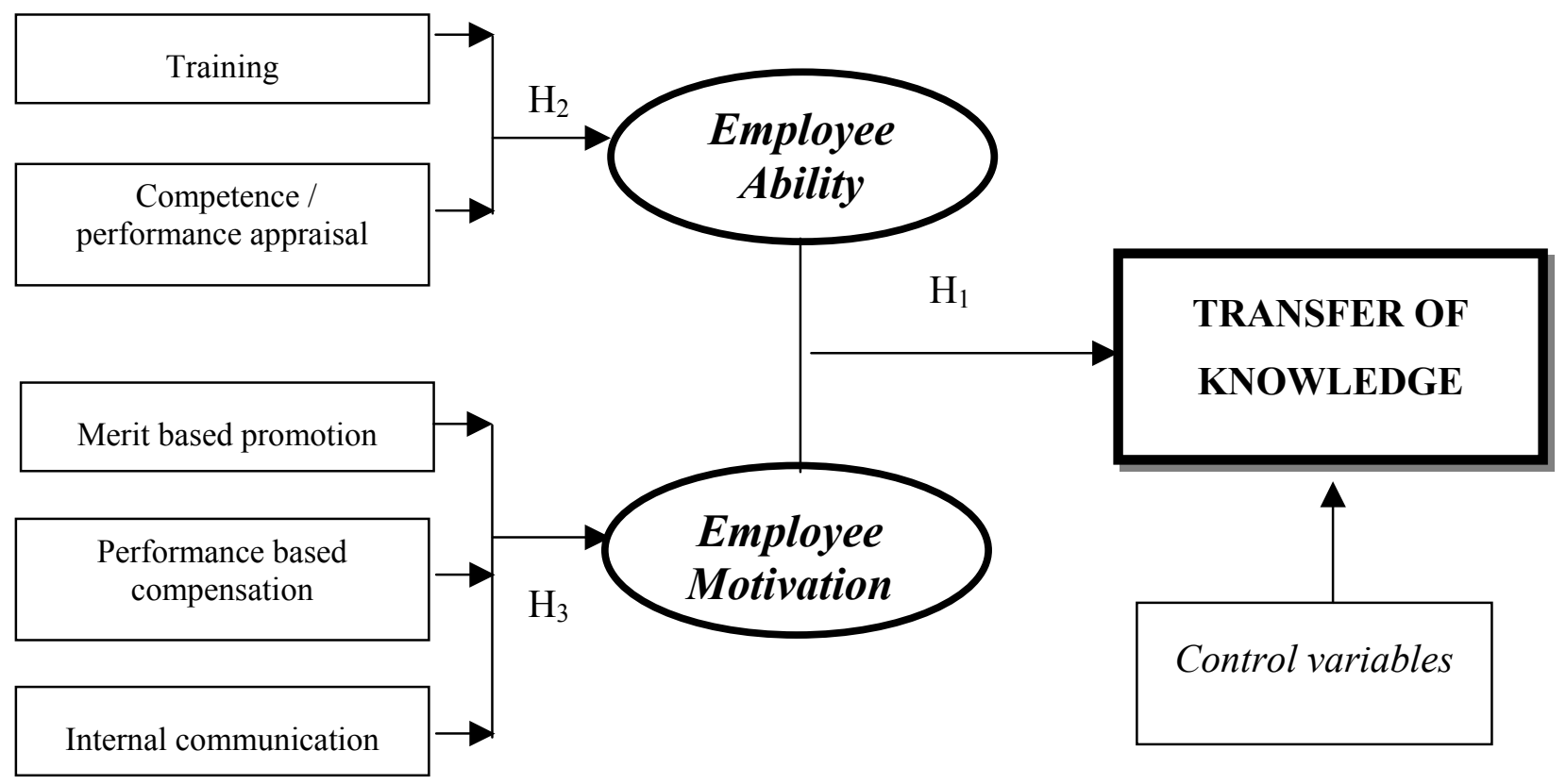

